\title{
Astyanax ajuricaba: a new species from the Amazon basin in Brazil (Characiformes: Characidae)
}

\author{
Manoela M. F. Marinhoํํㄹ and Flávio C. T. Lima²
}

A new Astyanax species is described from several localities in the rio Negro, rio Solimões and lower rio Tapajós basins, Amazon basin, Brazil. The new species is distinguished from all remaining characids by its unique color pattern consisting of the combination of presence of a conspicuous, narrow dark midlateral stripe, a well-developed vertically-elongated dark humeral spot, and upper caudal-fin lobe and middle caudal-fin rays dark, with a rounded clear ocellated spot present at anterior third of caudal-fin lobe.

Uma nova espécie de Astyanax é descrita de diversas localidades nas bacias dos rios Negro, Solimões e baixo Tapajós, bacia Amazônica, Brasil. A nova espécie pode ser distinguida de todos os demais Characidae por um padrão de colorido único, que consiste na combinação da presença de uma linha médio-lateral estreita e escura, uma mácula umeral escura bem desenvolvida e verticalmente alongada e o lobo superior da nadadeira caudal e raios medianos escuros, com uma mancha ocelada clara presente no terço anterior do lobo.

Key words: Rio Negro, Rio Tapajós, Moenkhausia lepidura species-group, Caudal-fin ocellated spot.

\section{Introduction}

Astyanax Baird \& Girard is the most speciose characid genus, currently comprising more than 100 valid species. Astyanax is widely distributed throughout the Americas, ranging from southern United States (Page \& Burr, 1991) to the río Colorado/río Negro basins in northern Patagonia, Argentina (Almirón et al., 1997; Casciotta et al., 2005). As could be expected from such a large, widespread fish assemblage, Astyanax systematics is very complex and still needs to be more thoroughly addressed. Eigenmann's (1921, 1927) revision of the genus remains the single attempt to tackle the genus in its entirety. The genus is not diagnosed by apomorphies, but rather, is defined by a combination of features (premaxillary teeth in two rows, the inner teeth row with five teeth, complete lateral line, caudal fin not scaled) that are broadly distributed among Characidae. As a consequence, the monophyly of Astyanax is at this time uncertain, and very likely the genus does not constitute a monophyletic entity.

The species described below was earlier reported by Géry (1992), based on a single specimen from the lago do Castanho (rio Solimões basin, Brazil), as a putative undescribed Astyanax species displaying a caudal-fin coloration unique within the genus, but shared with the Moenkhausia lepidura species complex: a dark mark on the upper caudal fin lobe. Géry (1992) noticed that, in spite of resembling the species of the Moenkhausia lepidura species complex, the undescribed Astyanax species possessed a high transversal scale count above lateral line when compared with specimens belonging to the Moenkhausia lepidura species complex, and, in addition, lack the typical scaled caudal-fin of Moenkhausia. Géry (1992) opted for not formally describing the species since he possessed a single, not perfectly preserved specimen. The second author collected additional material of this undescribed Astyanax during fieldwork in the rio Tiquié, upper rio Negro drainage, Brazil. Also, several lots ascribable to this species from the middle rio Negro and lower rio Tapajós basins

${ }^{1}$ UNESP, Universidade Estadual Paulista, Laboratório de Ictiologia, Departamento de Zoologia e Botânica. Rua Cristóvão Colombo, 2265, Jardim Nazareth, 15054-000 São José do Rio Preto, SP, Brazil. manumfm@yahoo.com.br

${ }^{2}$ Museu de Zoologia da Universidade de São Paulo, Caixa Postal 42494, 04299-970 São Paulo, SP, Brazil. fclima@usp.br 
were identified at the MZUSP and MPEG collections. We herein describe this species, and also provide remarks on its generic allocation.

\section{Material and Methods}

Morphometric and meristic data were taken following Fink \& Weitzman (1974) and Menezes \& Weitzman (1990), with the addition of the following measurements: dorsal and anal-fin base lengths, and eye to dorsal-fin origin and head depth, the latter measured at a vertical through the base of supraoccipital spine. In the description, counts are followed by their frequency in parentheses and asterisks indicate the holotype. Vertebrae of the Weberian apparatus were counted as four elements and the fused PU1+U1 of the caudal region as a single element. Counts of vertebrae, supraneurals, first branchial arch gill rakers, teeth cusps, maxillary teeth, dentary teeth, unbranched anal-fin rays and procurrent caudal-fin rays were taken from cleared and stained specimens (c\&s) prepared following the method of Taylor \& Van Dyke (1985). In the list of material examined, the number of whole specimens is given first, followed by the number of those cleared and stained (if any). Dentary and premaxillary bones were cleaned from soft tissues for scanning electron micrographs (SEM) images by a short (less than 10 minutes) immersion in weak (less than $1 \%)$ sodium hypochlorite solution and after that air-dried. Institutional abbreviations follow Reis et al. (2003), with the addition of DZSJRP (Departamento de Zoologia e Botânica, UNESP, São José do Rio Preto, São Paulo State, Brazil).

\section{Astyanax ajuricaba, new species Fig. 1}

Astyanax sp. Géry, 1992: 77, fig. 12 ("Lago do Castanha [ = Castanho], Solimões à environ 30 km au S.-O. de Manaus", Amazonas, Brazil; brief description, discussion).
Astyanax sp. 3. Cabalzar et al., 2005: 180 (upper rio Tiquié, rio Negro system, Amazonas, Brazil; figure; habitat notes).

Holotype. MZUSP 100231, 65.5 mm SL: Brazil, Amazonas State, stream tributary to rio Tiquié, Serra do Mucura village, $0^{\circ} 10^{\prime} 07^{\prime} \mathrm{N}$ 6907’46”W, 10 Sep 2006, F. C. T. Lima et al.

Paratypes. Brazil, Amazonas State, rio Negro drainage: MZUSP 92142, 22, 2 c\&s, 59.2-71.9 mm SL; ANSP 189235, 5, 59.3-68.3 mm SL; INPA 31196, 5, 64.3-66.5 mm SL, same data as the holotype. MZUSP 92365, 3, 62.8-88.6 mm SL, rio Tiquié, Serra do Mucura village, $0^{\circ} 10^{\prime} \mathrm{N} 69^{\circ} 07^{\prime} \mathrm{W}, 30$ Aug-12 Sep 2006, F. C. T. Lima et al. MZUSP 92252, 2, 66.4-68.1 mm SL, Doe Sehrako lake, rio Tiquié, below Pirarara-Poço village, $0^{\circ} 08^{\prime}$ N 69¹2'W, 07 Sep 2006, F. C. T. Lima et al.. MZUSP 81190, 1, 69.4 mm SL, rio Tiquié, Boca do Sal village, $0^{\circ} 16^{\prime 2} 22^{\prime \prime} \mathrm{N} 69^{\circ} 54$ '3’’W, 25 Oct 2002, N. P. Marques. MZUSP 62055, 1, 65.0 mm SL, rio Negro, Tapera, 0³1'S 65¹’W, 2 Nov 1972, Expedição Permanente à Amazônia. MZUSP 96045, 10, 54.4-66.5 mm SL, 1 c\&s, 60.6 mm SL, Santa Isabel do Rio Negro, lagoon at island in the rio Negro, $0^{\circ} 31^{\prime} \mathrm{S} 65^{\circ} 1^{\prime} \mathrm{W}, 14 \mathrm{Nov}$ 1972, Expedição Permanente da Amazônia. MPEG 694, 5, 34.5$61.2 \mathrm{~mm}$ SL, rio Negro, lagoon at Ilha de Tamanquaré, 253’S 60³1’W, 11 Nov 1984, M. Goulding. Pará, rio Tapajós drainage: MZUSP 21877, 83, 51.7-64.7 mm SL, 3 c\&s, 51.5-57.5 mm SL; USNM 394515, 5, 55.7-62.7 mm SL; DZSJRP 11286, 5, 59.3-64.7 mm SL; MCP 43346, 5, 52.7-60.0 mm SL, rio Tapajós, Maloquinha, near Itaituba, c. 4¹7'S 5559'W, 11-13 Nov 1970, Expedição Permanente à Amazônia. MZUSP 18280, 6, 62.5-95.2 mm SL, Igarapé Centrinho, Barreirinho, near São Luís, c. 4²6’'S 56²14’W, 24 Nov 1970, Expedição Permanente à Amazônia. MZUSP 18248, 24, 52.4-63.1 mm SL, Aveiro, igarapé Açu, 3³5'S 55²0'W, 30 Oct 1970, Expedição Permanente à Amazônia. MNRJ 33068, 1, 62.3 mm SL, Itaituba, igarapé Jacaré (tributary of rio Tapajós), Transamazônica road, 4²6’30.9”S 56¹4'10.8”'W, 28 Oct 2008, P. Buckup, C. Zawadzki, L. Fries, F. Carvalho \& F. Jerep.

Diagnosis. Astyanax ajuricaba can be diagnosed from all congeners, and in fact from all remaining characids by its unique color pattern consisting of the combination of presence of a conspicuous, narrow dark midlateral stripe, a single elongated humeral spot, and upper caudal-fin lobe and middle

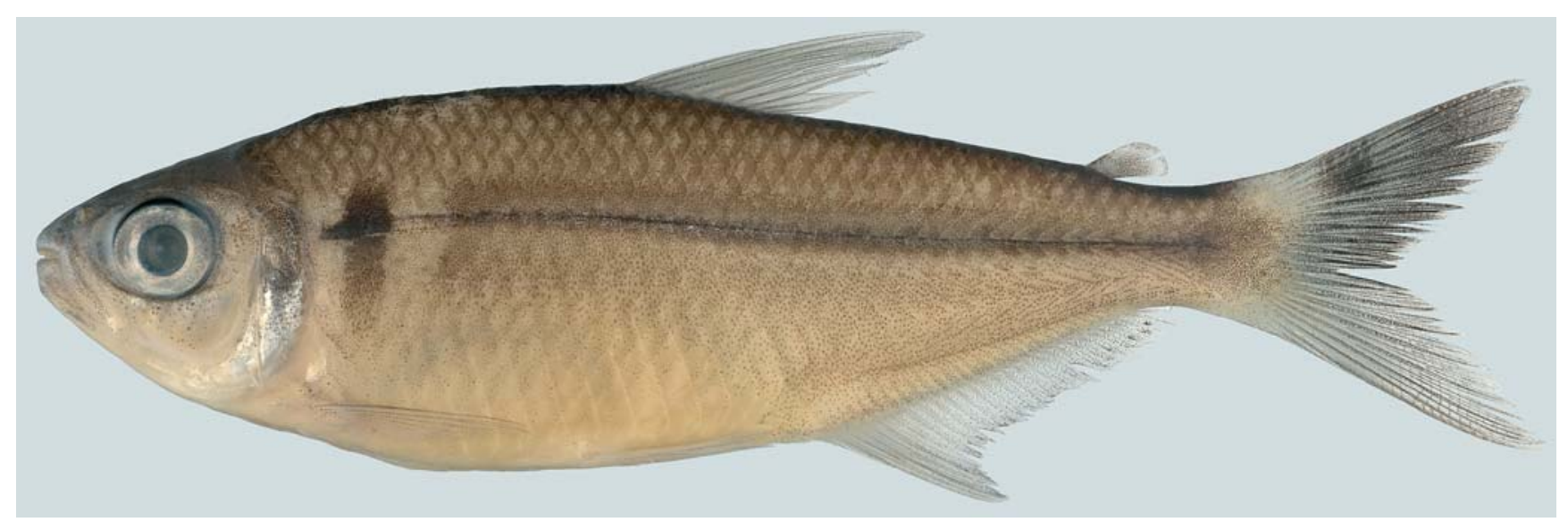

Fig. 1. Astyanax ajuricaba, holotype, MZUSP 100231, 65.5 mm SL: Brazil, Amazonas, rio Tiquié, Serra do Mucura village. 
caudal-fin rays dark, with a clear, rounded ocellated spot present dorsally at anterior third of caudal-fin lobe. See the Discussion for further details.

Description. Morphometric data for Astyanax ajuricaba is summarized in Table 1. Body elongated, compressed laterally. Largest specimen examined $95.2 \mathrm{~mm}$ SL. Greatest body depth immediately anterior to dorsal-fin origin. Dorsal profile of head slightly convex from snout tip to vertical through anterior nostril, and straight from that point to tip of supraoccipital spine. Predorsal profile of body slightly convex, posteroventrally slanted and straight from dorsal-fin origin to adipose-fin origin, slightly concave between latter point and origin of anteriormost dorsal procurrent caudal-fin ray. Ventral profile of head and body convex from lower lip to anal-fin origin; body profile along anal-fin base straight, posteroventrally inclined, and slightly concave between analfin terminus to anteriormost ventral procurrent caudal-fin ray.

Jaws equal, mouth terminal; posterior terminus of maxilla reaching vertical through anterior third of orbit. Premaxillary teeth in two rows, with midcentral cusp more developed than remaining cusps; outer teeth row with $4(6), 5^{*}(44)$, or $6(1)$ tricuspid teeth; inner tooth row with $4(5), 5^{*}(41)$ or $6(5)$ tri- to pentacuspid teeth. Maxillary with 1(5) or 2(2) uni- to tricuspid teeth; dentary with four large tetra- to pentacuspid teeth, followed by series of 7-10 small, unicuspid teeth (Fig. 2).

Dorsal-fin rays ii,9, not including small ossification anterior to first unbranched ray, discernible only in cleared and stained specimens; first unbranched ray about one-half length of second unbranched ray. Dorsal fin origin slightly ahead from midbody, at vertical through anterior third of pelvic-fin base, and base of its last ray at vertical through tip of adpressed pelvic fin. Tip of adpressed dorsal fin approximately at vertical through insertion of $8^{\text {th }}$ to $10^{\text {th }}$ branched anal-fin rays. First dorsal-fin pterygiophore inserting posterior to neural spine of $10^{\text {th }}$ (6) vertebrae. Pectoral-fin rays i,13*(27), 14(19), or 15(4). Adipose fin located approximately at vertical through insertion of $18^{\text {th }}$ to $24^{\text {th }}$ branched anal rays. Pelvic-fin rays i,7. Pectoral fin not reaching pelvic-fin insertion. Pelvic fin not reaching anal-fin origin. Anal-fin rays iv(5) or v(1), 23(2), 24(9), $25(21), 26^{*}(13)$, or $27(2)$. Last unbranched anal-fin ray and $1^{\text {th }}$ and $2^{\text {th }}$ branched rays longer; $3^{\text {th }}$ to $6^{\text {th }}$ branched rays decreasing abruptly in size; remaining branched anal-fin rays decreasing slightly in size. First anal-fin pterygiophore inserting posterior to neural spine of $18^{\text {th }}(6)$ vertebrae. Principal caudal-fin rays i,15,i(2), i,17,i*(49). Dorsal procurrent caudal-fin rays 12(1), 13(2), or 14(1), and ventral procurrent caudal-fin rays 10(3) or 11(1). Caudal-fin forked, lobes pointed. Scales at base of caudal fin, not extending over lobes. Supraneurals 4(3) or 5(3); upper portion with relatively poorly developed bony lamellae, more developed in specimens from rio Negro basin. Vertebrae 36(5) or 37(1). First gill arch with 2(4) or 3(1) hypobranchial, 9(1), 10(2), or 11(2) ceratobranchial, 1(5) on cartilage between ceratobranchial and epibranchial, and 7(4) or 8(1) epibranchial gill-rakers. Four branchiostegal rays: three branchiostegal rays originating at anterior ceratohyal and one at posterior ceratohyal.

Scales cycloid, with few radii along posterior border. Lateral line complete with 37(3), 38*(13), 39(22), 40(7), or 41(1) scales. Scale rows between dorsal-fin origin and lateral line $7(3), 8 *(48)$; scale rows between lateral line and pelvic-fin origin 5. Predorsal scales 13(14), 14*(29), 15(4), or 16(2).

Table 1. Morphometric data for Astyanax ajuricaba. Holotype (MZUSP 100231) and paratypes from rio Negro drainage (INPA 31196, $n=5$; MZUSP 92142, $n=25$ ), and specimens from the rio Tapajós drainage (DZSJRP 11286, $n=5$; MCP 43346, $n=5$; and MZUSP 21877, $\mathrm{n}=11$ ).

\begin{tabular}{|c|c|c|c|c|c|c|c|}
\hline \multirow{2}{*}{ Characters } & \multirow[b]{2}{*}{ Holotype } & \multicolumn{3}{|c|}{ rio Negro drainage } & \multicolumn{3}{|c|}{ rio Tapajós drainage } \\
\hline & & $\mathrm{n}$ & range & mean & $\mathrm{n}$ & range & mean \\
\hline Standard length & 65.5 & 30 & $59.2-71.9$ & - & 21 & $52.7-95.2$ & - \\
\hline \multicolumn{8}{|c|}{ Percents of standard length } \\
\hline Body depth & 31.8 & 30 & $28.4-32.2$ & 30.4 & 21 & 25.1-31.2 & 28.5 \\
\hline Snout to dorsal-fin insertion & 50.7 & 30 & $47.7-51.1$ & 49.6 & 21 & $47.6-51.5$ & 49.7 \\
\hline Snout to pectoral-fin insertion & 27.0 & 30 & $25.8-28.0$ & 26.9 & 21 & $25.2-28.1$ & 26.5 \\
\hline Snout to pelvic-fin insertion & 47.9 & 30 & 47.1-49.6 & 48.3 & 21 & $45.9-48.5$ & 47.3 \\
\hline Snout to anal-fin origin & 66.3 & 30 & $64.0-67.4$ & 65.4 & 21 & $63.9-67.2$ & 65.2 \\
\hline Caudal-peduncle depth & 9.6 & 30 & $8.5-9.6$ & 9.0 & 21 & $8.8-10.3$ & 9.5 \\
\hline Caudal-peduncle lenght & 10.4 & 30 & 9.9-11.9 & 10.7 & 21 & $9.6-13.0$ & 10.8 \\
\hline Pectoral-fin length & 19.1 & 30 & $17.6-20.4$ & 18.5 & 21 & $18.6-25.4$ & 19.7 \\
\hline Pelvic-fin length & 16.5 & 30 & $15.3-17.5$ & 16.3 & 21 & $15.8-17.8$ & 17.1 \\
\hline Anal-fin length & 15.1 & 30 & $14.2-16.8$ & 16.8 & 20 & 13.7-17.2 & 15.7 \\
\hline Anal-fin base length & 27.9 & 30 & $26.2-28.5$ & 27.3 & 21 & 25.6-29.1 & 27.3 \\
\hline Dorsal-fin length & 24.9 & 30 & $24.4-27.5$ & 25.6 & 21 & $24.6-28.0$ & 26.1 \\
\hline Dorsal-fin base length & 13.0 & 30 & $12.2-14.1$ & 13.0 & 21 & $12.2-14.5$ & 13.2 \\
\hline Eye to dorsal-fin origin & 37.1 & 30 & $34.1-37.7$ & 36.1 & 21 & $34.4-38.4$ & 36.3 \\
\hline Head depth & 25.0 & 30 & $23.5-26.6$ & 24.7 & 21 & $21.8-24.7$ & 23.3 \\
\hline Head length & 24.4 & 30 & $23.6-25.5$ & 24.6 & 21 & $23.2-25.8$ & 24.6 \\
\hline \multicolumn{8}{|c|}{ Percents of head length } \\
\hline Horizontal orbit diameter & 40.0 & 30 & $36.8-41.1$ & 38.6 & 21 & $35.7-41.2$ & 39.3 \\
\hline Snout length & 30.6 & 30 & $27.0-31.7$ & 29.1 & 21 & $26.5-30.2$ & 28.6 \\
\hline Interorbital width & 39.4 & 30 & $32.9-39.6$ & 35.7 & 21 & $32.4-38.0$ & 35.0 \\
\hline Upper-jaw length & 41.9 & 30 & $40.6-45.7$ & 43.0 & 21 & $38.0-42.7$ & 40.6 \\
\hline
\end{tabular}




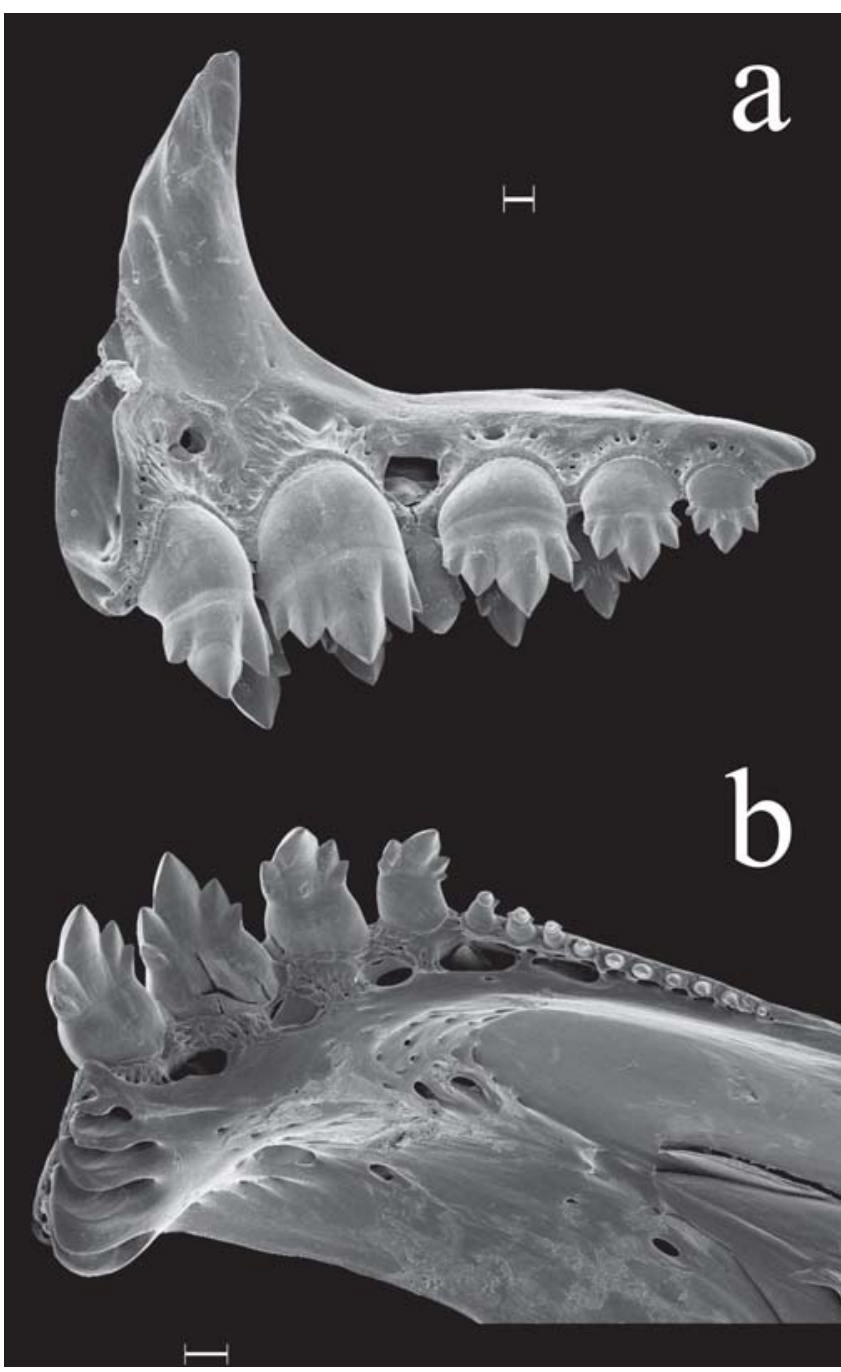

Fig. 2. Astyanax ajuricaba, MZUSP 96045, 60.6 mm SL; scanning electron micrographs (SEM) showing right premaxillary (a) and dentary teeth (b) in mesial view. Scale bar: (a): $100 \mu \mathrm{m}$; (b): $200 \mu \mathrm{m}$.

Circumpeduncular scale rows 14 . Single row of 5-8 scales covering base of anteriormost anal-fin rays.

Color in alcohol. Overall ground coloration of body pale. Top of head dark brown. Infraorbital, opercular areas and pectoral girdle silvery. Infraorbitals 5 and 6 and upper half of opercle with scattered, relatively large, dark chromatophores. Lower lip and anterior half of maxilla with dense concentration of small dark chromatophores. Gular area clear. Middorsal area dark brown. Scales above midlateral line, at dorsolateral portion of body bordered by dense concentration of small dark chromatophores, forming reticulated pattern. Humeral spot well defined, rectangular, vertically-elongated, extending vertically two scales rows above and one scale row below lateral line, and two scale rows horizontally. Humeral spot with darker area at level of midlateral line, extending beyond its anterior margin. Faint, wide, longitudinal dark band extending vertically through four scale rows: at lateral line and three scale rows above it, gradually narrowing towards and connecting to rounded faint blotch at caudal peduncle. Middlateral narrow dark stripe conspicuous, situated at junction of epaxial and hypaxial muscles, extending from first humeral blotch to caudal peduncle, but faint between humeral spots. Scattered dark chromatophores at posterior half of lower portion of body, between lateral line and anal-fin base, concentrating along margins of myosepta. Upper caudalfin lobe and middle caudal-fin rays darkened, except for clear rounded area (hereby defined as ocellated spot) present dorsally at anterior third of caudal-fin lobe. Black pigmentation on upper caudal-fin lobe and middle caudalfin rays not homogeneous, with intensity varying among specimens. Lower caudal-fin lobe and remaining fins with scattered dark chromatophores.

Color in life. Based on photographs of fresh collected paratypes, MZUSP 92252. Ground color pattern silvery, with top of head and dorsum dark grey. Narrow midlateral stripe not discernible due to silvery pigmentation. Upper half of eye yellowish. Caudal-fin ocellated spot, dorsal fin, adipose fin, and first anal-fin rays yellow.

Geographical variation. The only character to distinguish specimens of Astyanax ajuricaba from the rio Negro and rio Tapajós basins was the number of supraneural bones. Cleared and stained specimens from the rio Negro basin possess five, while specimens from rio Tapajós possess four supraneural bones.

Sexual dimorphism. No apparent sexual dimorphism was observed. Fin hooks, the usual dimorphic feature among characids (Malabarba \& Weitzman, 2003), were not found in any specimen.

Ecological notes. The type-locality of Astyanax ajuricaba is a black-water, terra-firme forest stream about 4-5 meters wide and 0.5-1.0 meters deep, with a predominantly sandy bottom. Specimens MZUSP 92252 were collected in a large oxbow lake of the rio Tiquié. According to field notes by P. Vanzolini, specimens from the igarapé Centrinho, in the rio Tapajós basin (MZUSP 18280), were collected in a small terra-firme stream, a habitat apparently similar to the type-locality.

Etymology. The specific epithet honors Ajuricaba, paramount chief of the Manau Indians, which formerly inhabited in the middle rio Negro area. During the decade of 1720, Ajuricaba leaded an unsuccessful attempt to resist the assaults of Portuguese slavers, which eventually lead to the defeat of his nation and his imprisonment. Ajuricaba averted a trial as a rebel by plunging in shackles into the rio Negro waters, and for such act of bravery he became a symbol of the resistance of the Indians against the Portuguese oppression (Hemming, 2004). 


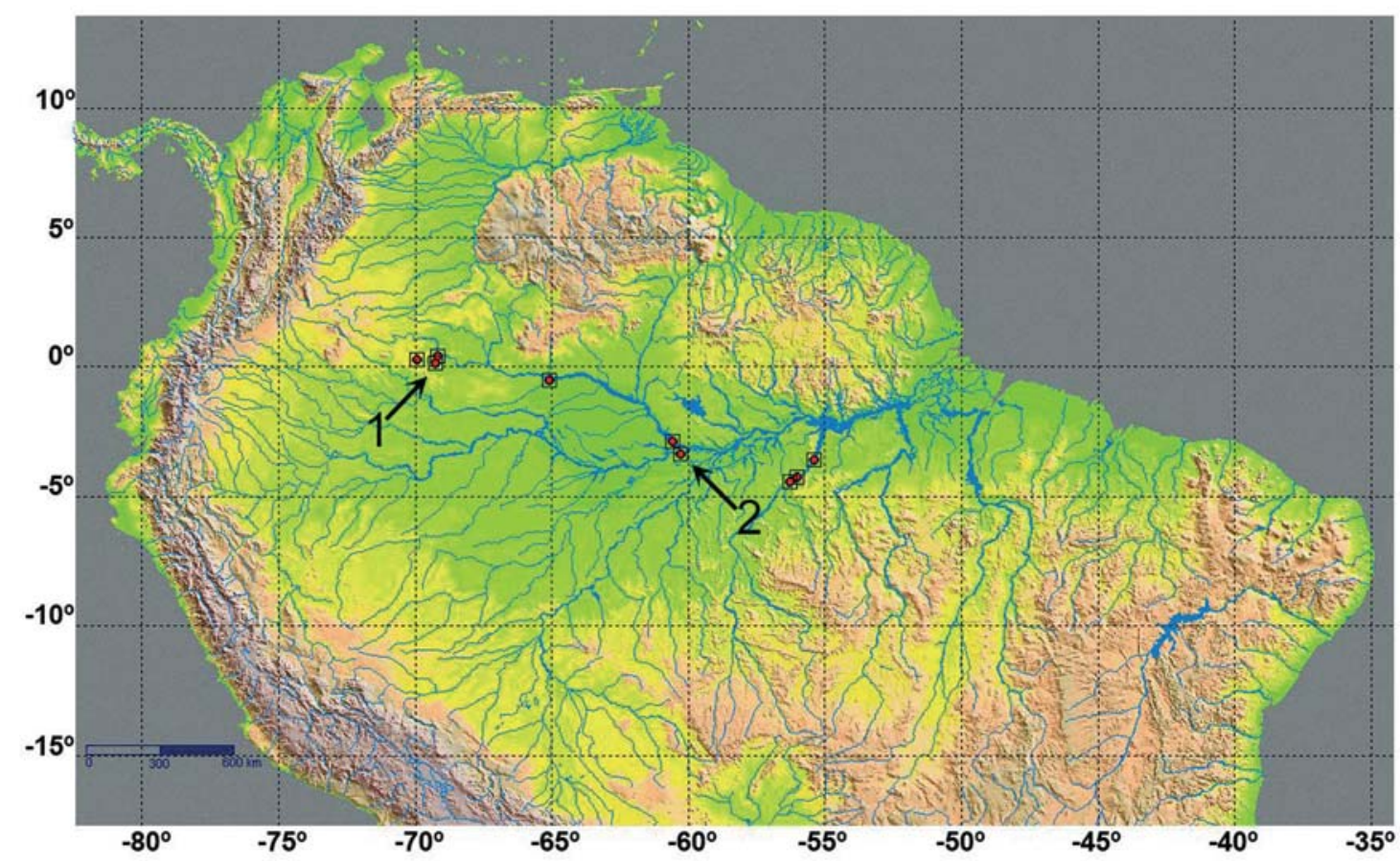

Fig. 3. Northern South America showing known localities of Astyanax ajuricaba. 1. Type locality. 2: Lago do Castanho, locality of the specimen examined by Géry (1992).

Popular names. Bose puri (Tukano language), Buse puri (Tuyuka language).

Distribution. Astyanax ajuricaba is known from the upper rio Negro basin at the rio Tiquié, a large tributary from the rio Uaupés, the middle and lower rio Negro areas at Santa Isabel do Rio Negro and Anavilhanas archipelago, respectively, and the lower rio Tapajós basin, Brazil. Géry (1992) recorded Astyanax ajuricaba (as Astyanax sp.) from the lago do Castanho (c. $3^{\circ} 23^{\prime} \mathrm{S} 60^{\circ} 13^{\prime} \mathrm{W}$ ), a large lake connected to the better-known lago Janauacá, both of which are situated at the floodplains of the rio Solimões, in the central Amazon basin (Fig. 3).

\section{Discusssion}

As indicated above, phylogenetic relationships within Astyanax are virtually unknown, and even the monophyly of the genus is highly doubtful. We herein concur with Géry (1992) in assigning the new species into Astyanax, since it fits the traditional definition of the genus. However, Astyanax ajuricaba does not resemble in overall external morphology neither the type-species of Astyanax, A. mexicanus (De Fillipi), nor most species currently assigned to the genus, which share a distinct color pattern, composed of red or yellow-colored caudal fins in life, a longitudinal dark midlateral stripe on caudal peduncle, and a single humeral spot. A proper assessment of the phylogenetic relationships of Astyanax ajuricaba must await detailed studies of phylogenetic relationships of Astyanax and related genera.

The caudal-fin pigmentation of Astyanax ajuricaba possesses, as noticed by Géry (1992), a remarkable similarity with the color pattern of the caudal fin of species belonging to the Moenkhausia lepidura complex, as well as to the pattern displayed by several Bryconops species, which consists in a dark upper caudal fin-lobe, with a clear-colored ocellated spot at the anterior third of the lobe. Due to the possession of a supraorbital bone, Bryconops has been considered as a basal genus within Characidae (Buckup, 1998; Malabarba \& Weitzman, 2003), and, as such, presumably is not closely related to Astyanax ajuricaba. As for the species belonging to the Moenkhausia lepidura species complex, Astyanax ajuricaba can be distinguished by the possession of 7-8 transversal scale rows above the lateral-line (vs. 5 transversal scale rows in the Moenkhausia lepidura species complex), by the absence of small scales on the anterior caudal-fin third (vs. presence), and by the presence of a narrow, well-defined midlateral stripe (vs. midlateral stripe broader and fainter).

Astyanax ajuricaba possess a single well-defined vertically-elongated humeral spot, with a darker area at the level of midlateral line, and a narrow, conspicuous midlateral dark stripe, extending from first humeral blotch to caudal peduncle. This combination of color markings resembles closely the color pattern presented by some Jupiaba species (J. abramoides, J. anteroides, and J. poranga), and also by Astyanax anterior. All those species are relatively high-bodied fishes (body height $>35.0 \%$ of SL), being quite distinct from Astyanax ajuricaba in overall body shape. More importantly, 
Jupiaba species also possess a well-developed spine-like process on the pelvic bone which constitutes a synapomorphy for the genus (Zanata, 1997). As it now stands, the available evidence does not seem to point for a close relationship between Astyanax ajuricaba and the Jupiaba species. However, a possible close relationship between Astyanax ajuricaba and A. anterior is a matter that merits further investigation.

Based on the similarity of the caudal-fin pigmentation and syntopy of Astyanax ajuricaba with species of the Moenkhausia lepidura species complex and some Bryconops species, Géry (1992) suggested a possible case of mimicry involving those different taxa. Astyanax ajuricaba is in fact collected syntopically across its range with species belonging both to the Moenkhausia lepidura species complex and Bryconops species displaying a similar caudal-fin pigmentation. Also, as pointed above, the presence of a similar caudal-fin pigmentation among at least Astyanax ajuricaba and the Moenkhausia belonging to the M. lepidura speciescomplex, on one hand, and the Bryconops species presenting this pattern, on other, constitutes almost certainly in an homoplastic feature. However, adequate field evidence is necessary to verify the plausibility of this possible mimetical ring involving Astyanax ajuricaba, Bryconops spp., and the Moenkhausia belonging to the $M$. lepidura species-complex.

Comparative material examined. Astyanax anterior: MZUSP 18277 (53, 62.1-111.3 mm SL). Jupiaba abramoides: MZUSP 85655 (12, 53.5- 76.0 mm SL). Jupiaba anteroides: MZUSP 30240 (15, 55.0-74.5 mm SL). Jupiaba poranga: MZUSP 17929 (7, 64.0-72.8 mm SL); MZUSP 93669 (1, 80.2 mm SL). Moenkhausia gracilima: MZUSP 15734 (4, 41.4-44.2 mm SL); MZUSP 5447 (13, 41.548.7 mm SL). Moenkhausia hysterosticta: MCP 32561 (15 paratypes, 38.9-45.2 mm SL). Moenkhausia lata: MZUSP 7921 (30 of 36, 33.2-41.5 mm SL). Moenkhausia lepidura: MZUSP 6227 (5 of 56, 64.8-67.0 mm SL); MZUSP 8181 (41, 34.4-66.9 mm SL); MZUSP 17977 (40, 58.7-77.3 mm SL); MZUSP 18220 (4, 65.982.8 mm SL); MZUSP 22083 (38, 59.3-72.2 mm SL); MZUSP 63192 (3, 50.3-53.8 mm SL); MZUSP 63196 (2, 48.9-56.5 mm SL); MZUSP 63236 (1, 50.8 mm SL). Moenkhausia loweae: MZUSP 44560 (holotype, 52.2 mm SL); MZUSP 44561 (2 paratypes, 50.051.1 mm SL); MZUSP 44563 (1 paratype, 48.3 mm SL).

\section{Acknowledgements}

We are grateful to Francisco Langeani for useful suggestions to the manuscript. Part of the type material of the new species was collected during expeditions of the project "Peixes e pesca no rio Tiquié", a joint collaboration of Instituto Sociambiental (ISA) and Federação das Organizações Indígenas do Alto Rio Negro (FOIRN). We are grateful to Aloísio Cabalzar and Mauro C. Lopes for help in the field. Special thanks are due to Tukano fishermen, especially Antenor, Roberval Pedrosa, and José Maria, for their assistance in collecting. A travel to Belém by the second author was funded by the Programa Calha-norte (Conservation International, Brazil/MPEG/Sema). Wolmar B. Wosiacki (MPEG) loaned material under his care. Lara G. Passos
(MZUSP) helped with SEM images. Alexandre C. Ribeiro prepared Figure 3. Eduardo G. Baena prepared Figure 1 and edited Figures 2 and 3. The authors were funded by CAPES (MMFM) and FAPESP (grant 07/02978-7; FCTL).

\section{Literature Cited}

Almirón, A., M. M. Azpelicueta, J. Casciotta \& A. L. Cazorla. 1997. Ichthyogeographic boundary between the Brazilian and austral subregions in South America, Argentina. Biogeographica, 73: 23-30.

Buckup, P. A. 1998. Relationships of the Characidiinae and phylogeny of characiform fishes (Teleostei: Ostariophysi). Pp. 123-144. In: Malabarba, L. R., R. E. Reis, R. P. Vari, Z. M. S. Lucena \& C. A. S. Lucena (Eds.). Phylogeny and classification of Neotropical fishes. Porto Alegre, Edipucrs, 603p.

Cabalzar, A., F. C. T. Lima \& M. C. Lopes. 2005. Peixes e gente no alto rio Tiquié: conhecimento Tukano e Tuyuka, ictiologia, etnologia. São Paulo, Instituto Socioambiental, 339p.

Casciotta, J. R., A. E. Almirón \& M. M. Azpelicueta. 2005. Astyanax pampa (Characiformes, Characidae), a new species from the southernmost boundary of the Brazilian subregion, Argentina. Revue Suisse de Zoologie, 112: 401-408.

Eigenmann, C. H. 1921. The American Characidae. Memoirs of the Museum of Comparative Zoology, 43: 209-310.

Eigenmann, C. H. 1927. The American Characidae. Memoirs of the Museum of Comparative Zoology, 43: 311-428.

Fink, W. L. \& S. H. Weitzman. 1974. The so-called Cheirodontin fishes of Central America with description of two new species (Pisces, Characidae). Smithsonian Contributions to Zoology, 172: 1-46.

Géry, J. 1992. Description de deux nouvelles espèces proches de Moenkhausia lepidura (Kner) (Poissons, Characiformes, Tetragonopterinae), avec une revue du groupe. Revue Française d’Aquariologie et Herpétologie, 19: 69-78.

Hemming, J. 2004. Red Gold: the conquest of the Brazilian Indians. London, Pan Books, 685p.

Malabarba, L. R. \& S. H. Weitzman. 2003. Description of a new genus with six new species from southern Brazil, Uruguay and Argentina, with a discussion of a putative characid clade (Teleostei: Characiformes: Characidae). Comunicações do Museu de Ciências e Tecnologia da PUCRS, Série Zoologia, 16: 67-151.

Menezes, N. A. \& S. H. Weitzman. 1990. Two new species of Mimagoniates (Teleostei: Characidae: Glandulocaudinae), their phylogeny and biogeography and a key to the glandulocaudin fishes of Brazil and Paraguay. Proceedings of the Biological Society of Washington, 103: 380-426.

Page, L. M. \& B. M. Burr. 1991. A field guide to freshwater fishes. North America north of Mexico. Boston, Houghton Mifflin Co., 432p.

Reis, R. E., S. O. Kullander \& C. J. Ferraris, Jr. (Eds). 2003. Checklist of the freshwater fishes of South and Central America. Edipucrs, Porto Alegre, 729p.

Taylor, W. R. \& G. C. Van Dyke. 1985. Revised procedures for staining and clearing small fishes and other vertebrates for bone and cartilage study. Cybium, 9: 107-109.

Zanata, A. 1997. Jupiaba, um novo gênero de Tetragonopterinae com osso pélvico em forma de espinho (Characidae, Characiformes). Iheringia, série Zoologia 83: 99-136.

Accepted March 2009

Published June 17, 2009 